\title{
5'-3' Exoribonuclease 2
}

National Cancer Institute

\section{Source}

National Cancer Institute. 5'-3' Exoribonuclease 2. NCI Thesaurus. Code C94710.

5'-3' exoribonuclease 2 (950 aa, $109 \mathrm{kDa}$ ) is encoded by the human XRN2 gene. This protein is involved in the mediation of RNA metabolism. 